\title{
RELEVANSI LULUSAN PROGRAM STUDI PENDIDKAN KIMIA DENGAN KEBUTUHAN PASAR KERJA
}

\section{RELEVANCE OF CHMISTRY EDUCATION GRADUATES TOWARD WORKING PLACE REQUIREMENT}

\author{
Eka Junaidi, Yunita Arian Sani Anwar, Saprizal Hadisaputra*
}

\author{
Program Studi Pendidikan Kimia, Jurusan Pendidikan MIPA, FKIP, Universitas Mataram
}

*Email : rizal@unram.ac.id

Diterima: 11 Desember 2018. Disetujui: 03 Maret 2019. Dipublikasikan:31 Maret 2019

\begin{abstract}
Abstrak. Penelitian ini bertujuan untuk melakukan pemetaan profil lulusan program studi pendidikan kimia FKIP Universitas Mataram dengan kebutuhan pasar kerja di tingkat Nasional. Penelitian ini merupakan penelitian deskriptif yang bersifat memberikan penjelasan terkait dengan profil alumni program studi pendidikan Kimia FKIP Universitas Mataram. Adapun pelaksanaan penelitian ini dilakukan melalui tracer study yang umumnya menggunakan instrumen, berupa kuesioner online karena dianggap memiliki kelebihan, yaitu lebih menghemat biaya, data dimasukan sendiri oleh responden ke dalam sistem, keluaran hasil yang lebih cepat karena data terkoleksi di sistem sehingga pengolahan lebih cepat dilakukan, serta tingginya jumlah responden yang mungkin didapat. Pelaksanaan tracer study pada dasarnya dilakukan dengan mengikuti tiga tahapan. Tahap awal yaitu pengembangan konsep dan instrumen. Tahapan kedua adalah pengumpulan data responden (alumni Program Studi). Tahap akhir adalah analisis data dan penulisan laporan. Untuk analisis data hasil penelitian digunakan teknik deskriptif kuantitatif berupa persentase sederhana dan penggunaan tabel. Untuk keperluan pengolahan data yang bersifat kualitatif dilakukan analisis melalui tiga jalur yaitu reduksi data, penyajian data dan penarikan kesimpulan. Adapun yang menjadi sampel dalam penelitian ini adalah seluruh responden alumni pendidikan kimia mulai angkatan 1997 (angkatan pertama) sampai dengan angkatan 2013 yang berjumlah 189 orang. Berdasarkan hasil tabulasi dan analisis data responden diperoleh informasi bahwa Alumni Program Studi Pendidikan Kimia diketahui bahwa; 1.) Jumlah lulusan pendidikan kimia yang telah terserap dunia kerja sebanyak 79,9 \% pada berbagai sektor pekerjaan; 2.) Bidang Pekerjaan pertama yang diperoleh setelah lulus adalah sebagai guru/Dosen Mata Pelajaran Kimia yaitu sebanyak 36,5 \%; 3.) Bidang pekerjaan alumni Pendidikan Kimia yang sesuai dengan keilmuannya sebanyak 56,6 \% dengan bidang pekerja yang paling banyak adalah sebagai Guru Mata Pelajaran Kimia (39,2\%); 4.) Kesesuaian pengetahuan dan keterampilan yang diperoleh dari program studi dengan tuntutan pekerjaanya (kesesuaian lebih dari $81 \%$ ) adalah 40,7 \%; dan 5.) Status kepegawaian alumni paling banyak adalah sebagai pegawai honorer/kontrak/tetap sebanyak 43,9\%.
\end{abstract}

Kata Kunci: Tracer Study, Deskriptif, Profil Lulusan, alumni

This study aims to analyze the relevance of alumni of chemical education study programs, faculty of teacher training and education, university of mataram to the needs of the labor market. This research is a descriptive study that uses an tracer study instrument in the form of an online questionnaire. The method was chosen because it saves costs, fast, easy data processing and good results accuracy. Tracer study is carried out in three stages. The first stage is the development of concepts and instruments. The second stage is collecting data from respondents/alumni. The final stage is data analysis and report writing. Quantitative descriptive techniques are used to process data presented in the form of simple percentages and tables. For the purposes of qualitative data processing, analysis is carried out through three paths, namely data reduction, data presentation and conclusion drawing. The study sample was alumni of the chemistry class of 1997 to 2013, correspond to 189 respondents. The results of tabulation and analysis of respondents' data indicate: 1.) The number of chemical education graduates who have been absorbed by the workplace is $79.9 \%$ in various occupational sectors; 2.) The alumni first job after graduating as a chemistry teacher or lecturer has a percentage of $36.5 \%$; 3.) The percentage of alumni who work in the field of chemistry is as much as $56.6 \%$, with the highest number of workers being chemistry teachers $(39.2 \%)$; 4.) Suitability of knowledge and skills obtained from study programs with job demands has a percentage of $40.7 \%$ with a suitability level of more than $81.0 \%$; and 5.) Most alumni jobs are outsourcing employees $43.9 \%$.

Keywords: Tracer Study, Descriptive, Profile of Graduates, Alumni

\section{PENDAHULUAN}

Program studi pendidikan kimia merupakan salah satu program studi pada Fakultas Keguruan dan Ilmu Pendidikan Universitas Mataram. Meskipun SK pendirian program studi tertanggal 31 Januari 2001 dengan nomor SK 
31/DIKTI/Kep/2001, akan tetapi penyelenggaraan penerimaan mahasiswa program studi pendidikan kimia telah dilaksanakan sejak tahun 1997. Program studi pendidkan kimia sampai saat ini telah memiliki lulusan (alumni) tidak kurang dari 15 angkatan (sekitar 600 orang). Jumlah lulusan yang cukup besar memungkinkan program studi tidak memiliki rekam jejak terhadap lulusannya. Kondisi ini mengakibatkan hampir tidak ada umpan balik dari lulusan untuk perbaikan kualitas pendidikan program studi. Umpan balik yang diberikan alumni, pada umumnya dapat bermanfaat dalam membantu program studi untuk perbaikan sistem dan pengelolaan pendidikan. Sebagai bagian dari institusi, keberadaan alumni merupakan hal yang sangat penting untuk melihat dan menilai tingkat keberhasilan pola pendidikan dan kurikulum yang telah dijalankan [1-6].

Melalui profil alumni (lulusan), masyarakat akan menilai kiprah dan kontribusi alumni dalam pembangunan sesuai relevansi pendidikannya dan membuktikan kualitas sebuah institusi pendidikan. Melalui kiprah alumni pula nama baik dan kredibilitas program studi dipertaruhkan. Untuk mengetahui informasi yang terkait dengan alumni, salah satu metode yang dapat digunakan untuk membantu perguruan tinggi (program studi) dalam perbaikan sistem dan pengelolaan pendidikan adalah dengan melaksanakan tracer study. Tracer study merupakan salah satu studi yang mampu menyediakan informasi bermanfaat bagi kepentingan evaluasi program studi dan selanjutnya dapat digunakan untuk penyempurnaan dan penjaminan kualitas pendidikan yang dilakukan program studi. Tracer study juga dapat dimanfaatkan program studi dalam menyediakan informasi penting mengenai hubungan antara program studi dan dunia kerja, menilai relevansi program studi, informasi bagi pemangku kepentingan (stakeholders), dan kelengkapan persyaratan bagi akreditasi program studi [7-8].

Tracer study merupakan pendekatan yang memungkinkan institusi pendidikan tinggi memperoleh informasi tentang kekurangan yang mungkin terjadi dalam proses pendidikan. Tracer study perlu dilakukan secara melembaga, terstruktur dan dengan metodologi dan analisis yang tepat untuk memperoleh hasil yang terukur, akurat dan dapat diperbandingkan. Seringkali tracer study dilakukan oleh perguruan tinggi hanya karena kebutuhan sesaat yang salah satunya adalah untuk kepentingan akreditasi program studi sehingga pelaksanaannya tidak dilakukan secara rutin atau berkelanjutan dan tidak melembaga. Melihat pentingnya pelaksanaan tracer study sebagai suatu kajian penyedia informasi profil lulusan yang valid, tracer study dapat pula digunakan sebagai dasar kegiatan perencanaan masa depan program studi yang berhubungan dengan perbaikan akan pelayanan pendidikan [9$11,13-15]$

Oleh karena itu diperlukan penelitian yang dapat memberikan gambaran yang utuh tentang profil alumni sehingga dapat meningkatkan kinerja progrm studi pendidikan kimia FKIP Universitas Mataram. Peningkatan kinerja program studi ini sangat diperlukan dalam rangka memberikan jaminan kepada masyarakat untuk menghasilkan lulusan (alumni) yang profesional dan memiliki kemampuan daya saing yang tinggi, sebagaimana yang tercantum pada visi program studi pendidikan kimia yaitu menghasilkan calon tenaga pendidik dan kependidikan dalam bidang kimia yang berkualitas dan berdaya saing internasional melalui pendidikan dan pembelajaran berbasis riset pada tahun 2025.

Penelitian ini bertujuan untuk melakukan pemetaan profil lulusan program studi pendidikan kimia FKIP Universitas Mataram dan relevansinya dengan dunia kerja. Tujuan tersebut kemudian di breakdown menjadi beberapa tujuan khusus diantaranya: 1). Program studi akan memiliki informasi data alumni yang konprehensif yang dapat dijadikan sebagai acuan refleksi kinerja program studi pendidikan kimia FKIP Universitas Mataram, 2). Mengetahui profil alumni program studi pendidikan Kimia FKIP Universitas Mataram dalam pasar kerja, 3). Memberikan rekomendasi untuk meningkatkan kinerja program studi pendidikan Kimia FKIP Universitas Mataram, 4). Bahan untuk membangun jaringan/network antara program studi dengan alumni. Tujuan tersebut dapat dicapai melalui langkah-langkah penelitian menggunakan penyebaran angket atau kuisioner atau bentuk lain melalui media sosial dengan tujuan mendapatkan informasi sebanyak mungkin tentang alumni program studi pendidikan kimia FKIP Universitas Mataram.

Dari penelitian ini diharapkan pula program studi akan memiliki data alumni yang lengkap serta mendapatkan feedback untuk perbaikan dan penguatan program studi dalam mewujudkan misi program studi sesuai dengan yang dicita - citakan yakni 1). Menyelenggarakan pendidikan dan pembelajaran yang bermutu tinggi; 2). Melaksanakan penelitian, pengembangan dalam bidang kimia dan pendidikan kimia; 3). Memberikan layanan kepada masyarakat secara profesional dalam bidang ilmu kimia dan pendidikan kimia; 4). Membangun dan memperkokoh jejaring dan kemitraan dengan stakeholder di tingkat nasional, regional dan internasional.

\section{METODE PENELITIAN}

Penelitian ini merupakan penelitian diskriptif yang bersifat memberikan penjelasan terkait dengan profil alumni program studi pendidikan Kimia FKIP Universitas Mataram. Penelitian ini 
dilaksanakan pada bulan Juli - Oktober 2018. Populasi dalam penelitian ini adalah seluruh alumni Program Studi Pendidikan Kimia FKIP Universitas Mataram yang diperkirakan sekitar 600 orang (15 Angkatan@40 orang). Sedangkan sampel dalam penelitian ini adalah seluruh alumni mulai angkatan pertama (1997) sampai dengan angkatan 2013 yang memberikan respons terhadap angket penelusuran alumni yang disebar dengan mengacu pada basis data yang sudah dikembangkan dan diterima kembali oleh peneliti. Hasil isian respon alumni ini akan dijadikan sebagai dasar untuk pembuatan basis data alumni.

Pelaksanaan tracer study yang dilakukan saat ini pada umumnya menggunakan instrumen, berupa kuesioner online. Kuesioner online digunakan karena dianggap memiliki kelebihan, yaitu lebih menghemat biaya (tidak perlu mencetak dan mengirimkan lewat pos), tidak membutuhkan banyak staf dalam penyebarannya (data dimasukan sendiri oleh responden ke dalam sistem), keluaran hasil yang lebih cepat (data terkoleksi di sistem sehingga pengolahan lebih cepat dilakukan), dan tingginya jumlah responden yang mungkin didapat (kuesioner dapat dimodifikasi sehingga tampak pendek). Sedangkan tahapan Pelaksanaan Tracer Study terdiri atas tiga tahapan; 1). Tahap awal pelaksanaan berupa pengembangan konsep dan instrumen (concept and instrument development), 2). Tahapan pengumpulan data (data collection), 3). Tahap akhir adalah analisis data dan penulisan laporan (data analysis and report writing). Untuk tahap Analisis, data yang diperoleh ditabulasi dan diolah secara otomatis oleh sistem dalam bentuk statistik diskriptif berupa tabel yang dapat dilihat secara langsung hasilnya pada saat pengisian data setelah selesai dilakukan responden. Data tersebut kemudian diidentifikasi berdasarkan aspek-aspek seperti dijelaskan pada form kuesioner. Alur penelitian yang akan dilakukan dimuat dalam gambar 2.

Semua data yang dikumpulkan melalui angket dianalisis dengan menggunakan teknik analisis deskriptif persentase. Data disajikan dalam bentuk tabel dan gambar untuk melihat kecenderungan kesesuaiannya. Aktivitas dalam analisis data terdiri dari: 1). Reduksi Data. Mereduksi data berarti merangkum, memilih halhal yang pokok, memfokuskan pada hal- hal yang penting, dicari tema dan polanya dan membuang yang tidak perlu". Dengan dilakukannya reduksi data, maka akan diperoleh data yang lebih jelas, 2). Penyajian Data. Penyajian data dilakukan setelah data direduksi. Penyajian data dapat dilakukan dalam bentuk tabel, grafik, pie chart, pictogram dan sejenisnya (Sugiyono, 2010). Penyajian data yang dilakukan agar memudahkan peneliti menarik kesimpulan, 3). Penarikan Kesimpulan. Penarikan kesimpulan merupakan upaya yang dilakukan untuk mencari makna mungkin dapat menjawab rumusan masalah yang sudah dirumuskan. Langkah akhir ini diikuti pula dengan kegiatan menyusun rekomendasi.

\section{HASIL PENELITIAN DAN PEMBAHASAN} 1.1. Data Responden

Setelah dilakukan tabulasi data diperoleh jumlah responden (Alumni) yang turut berpartisipasi dalam pengisian quesioner tracer study terdistribusi berdasarkan tahun masuk dari angkatan 1997 (Angkatan pertama) sampai tahun masuk 2013 sebagaimana yang ditampilkan pada Gambar 3.

Berdasarkan Gambar (3), di atas diperoleh data jumlah responden sebanyak 189 orang alumni (setara dengan 31,5\% dari perkiraan populasi lulusan program studi pendidikan kimia sekitar 600 orang). Jumlah responden terbanyak diperoleh berasal dari mahasiswa angkatan 2009 dan 2011 sebanyak 24 responden (12,7\%), sedangkan yang paling sedikit responden adalah mahasiswa angkatan 2002 sebanyak 1 responden $(0,5 \%)$.

\subsection{Profil Lulusan Program Studi Pendidikan Kimia}

Berdasarkan respon Alumni yang telah dikumpulkan, profil lulusan program studi pendidikan kimia digambarkan dalam bentuk; 1). Pekerjaan Pertama setelah Lulus, 2). Pekerjaan Alumni Saat Ini, 3). Status Kepegawaian Alumni, dan Status 4). Pendidikan Lanjutan Alumni.

\section{Pekerjaan Pertama Alumni Setelah Lulus} Jenis pekerjaan yang diperoleh pertama Alumni digambarkan terdapat pada gambar 4 . Berdasarkan gambar (4) diperoleh informasi bahwa, pekerjaan pertama yang diperoleh alumni adalah sebagai guru/Dosen Mata Pelajaran Kimia Sebesar 36,5\%, sebagai instruktur bimbingan belajar 28,6\%, bekerja bidang non kimia $12,2 \%$, Wiraswasta $6,9 \%$, Guru/Dosen mata Pelajaran non Kimia 6,3\%, Melanjutkan Studi 4,2\%, tidak/belum bekerja 2,1\%, Laboran Kimia $1,6 \%$ dan sebagai Instruktur/guru Bimbingan Belajar Bidang non kimia sebesar $1,6 \%$.

\section{Pekerjaan Alumni Saat Ini}

Adapun jenis pekerjaan alumni pada saat ini berdasarkan hasil tabulasi data alumni, diperoleh informasi yang termuat pada gambar 5. Jenis Pekerjaan alumni saat ini adalah : sebagai guru Mata Pelajaran Kimia Sebesar 39,2\%, Bekerja di bidang non kimia 15,3\%, Tidak/Belum Bekerja $9,0 \%$, sebagai instruktur bimbingan belajar kimia 9,0\%, Wiraswasta 7,9\%, Guru mata Pelajaran non Kimia 7,4\%, Dosen Bidang Kimia 6,3\%, Mahasiswa 3,2\%, Laboran Kimia 2,1\%, dan Dosen bidang non kimia $0,5 \%$. 


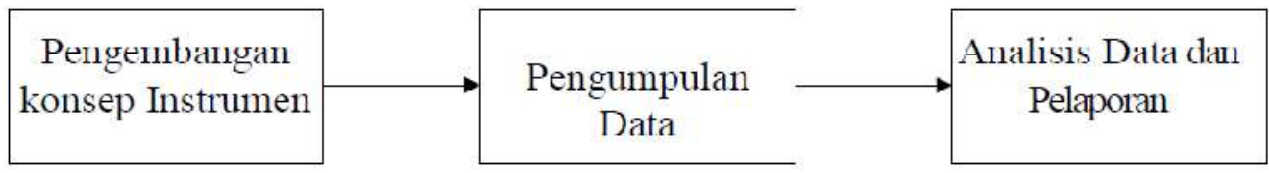

Gambar1.Tahapan Survey Alumni Program Studi Pendidikan Kimia

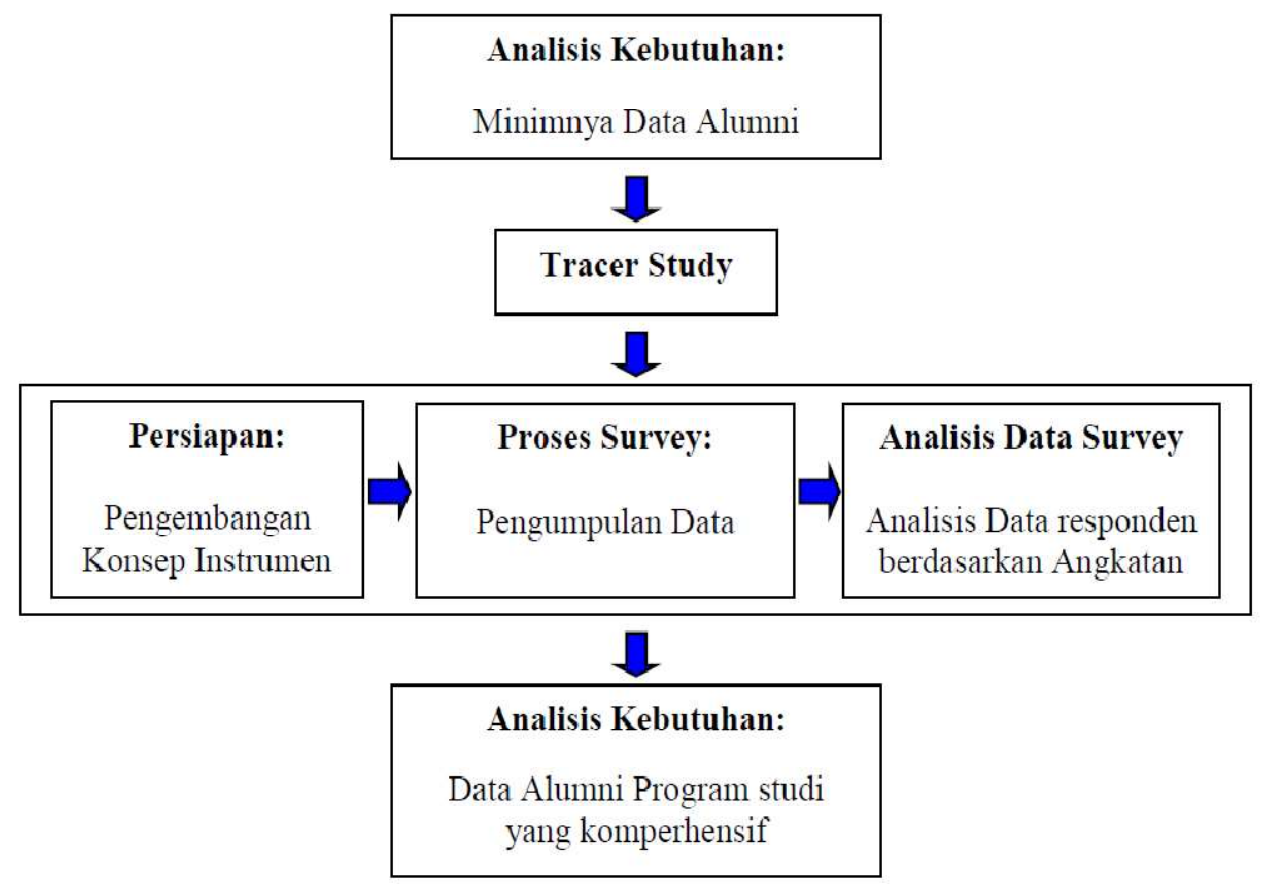

Gambar 2. Bagan Alur Pelaksanaan Penelitian

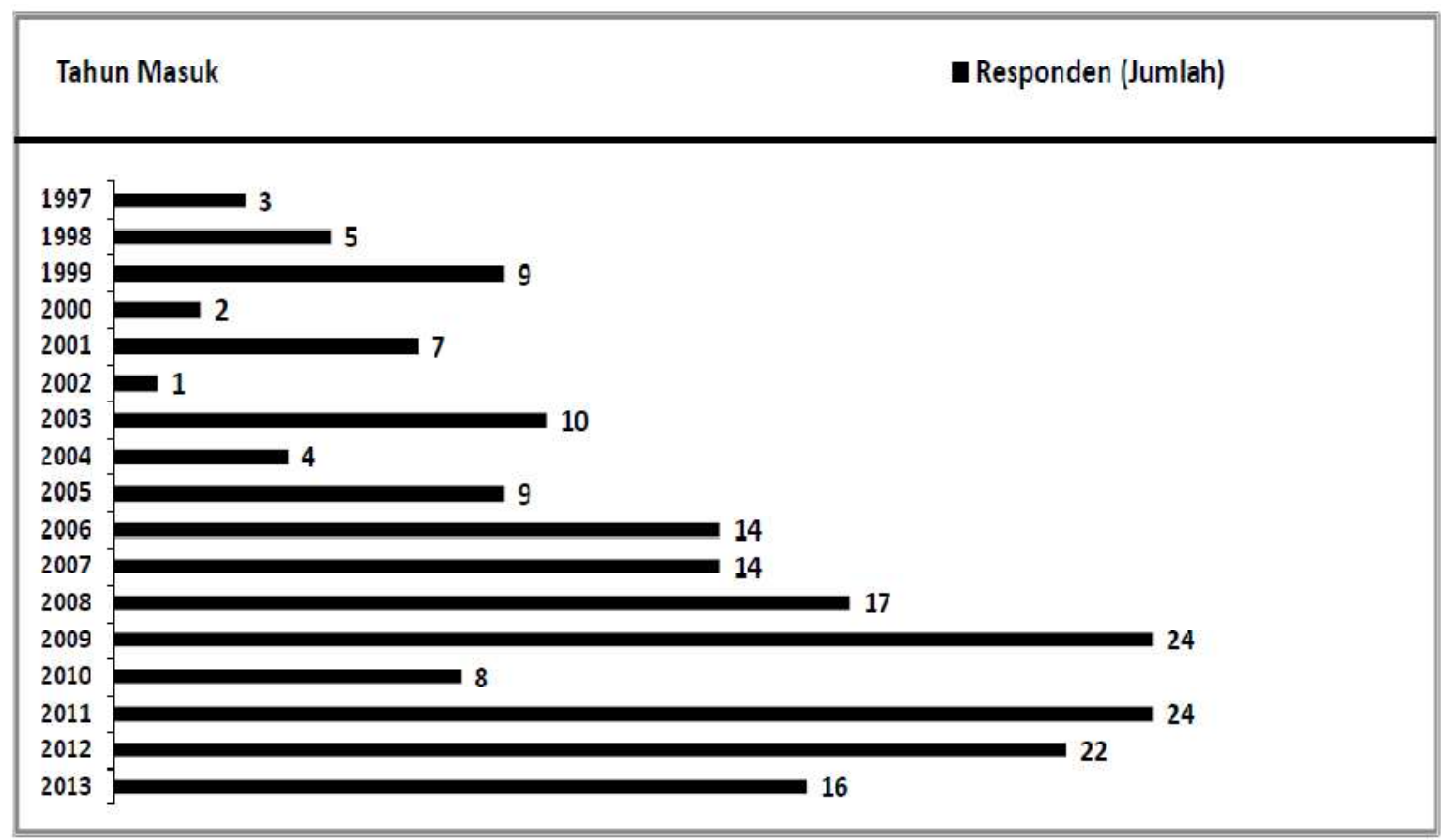

Gambar 3. Jumlah Responden Berdasarkan Tahun Masuk 


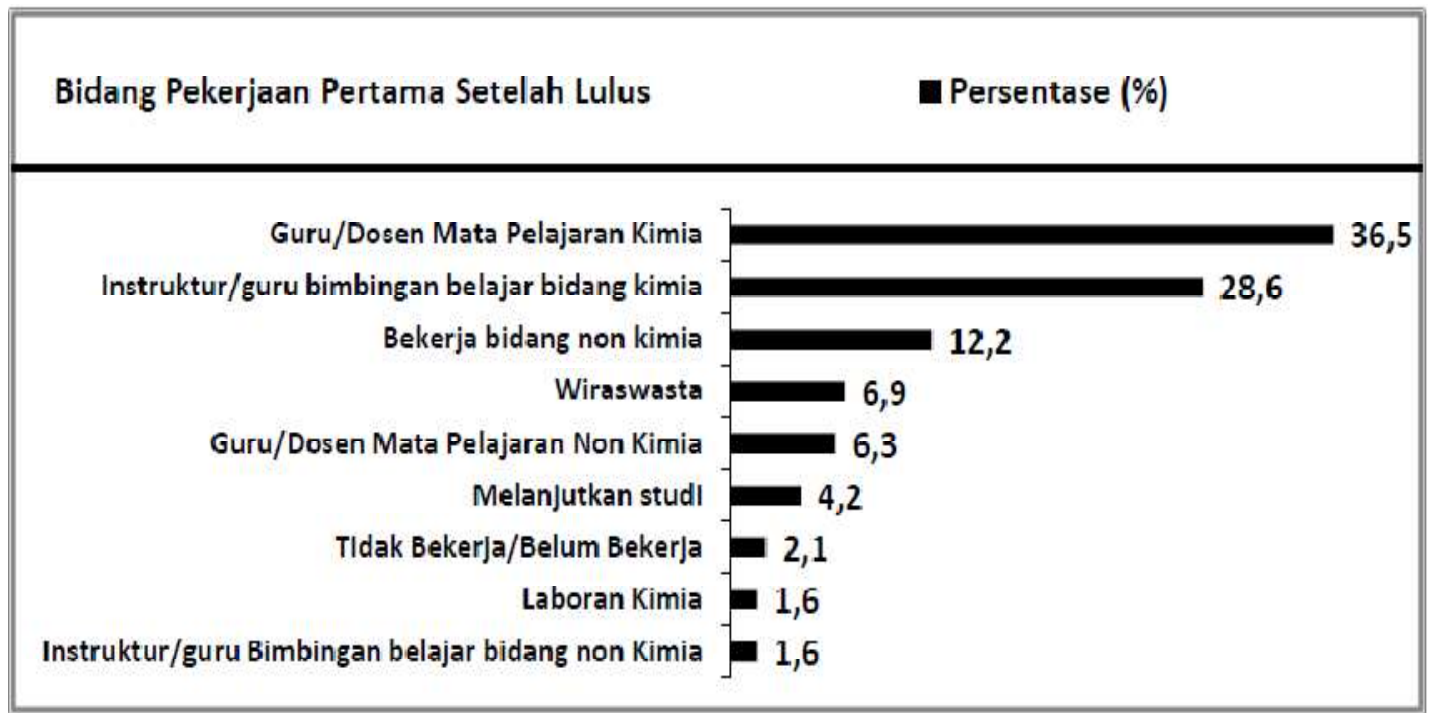

Gambar 4. Bidang Pekerjaan Pertama Alumni Setelah Lulus

\begin{tabular}{|r|r|}
\hline Bidang Pekerjaan Saat Ini & Persentase (\%) \\
\hline Guru Mata Pelajaran Kimia \\
Bekerja bidang non kimia \\
Tidak Bekerja/Belum Bekerja \\
Instruktur/guru bimbingan belajar bidang kimia \\
Wiraswasta \\
Guru Mata Pelajaran Non Kimia \\
Dosen bidang kimia \\
Mahasiswa \\
Laboran Kimia \\
Dosen bidang Non kimia
\end{tabular}

Gambar 5. Bidang Pekerjaan Alumni Saat Ini

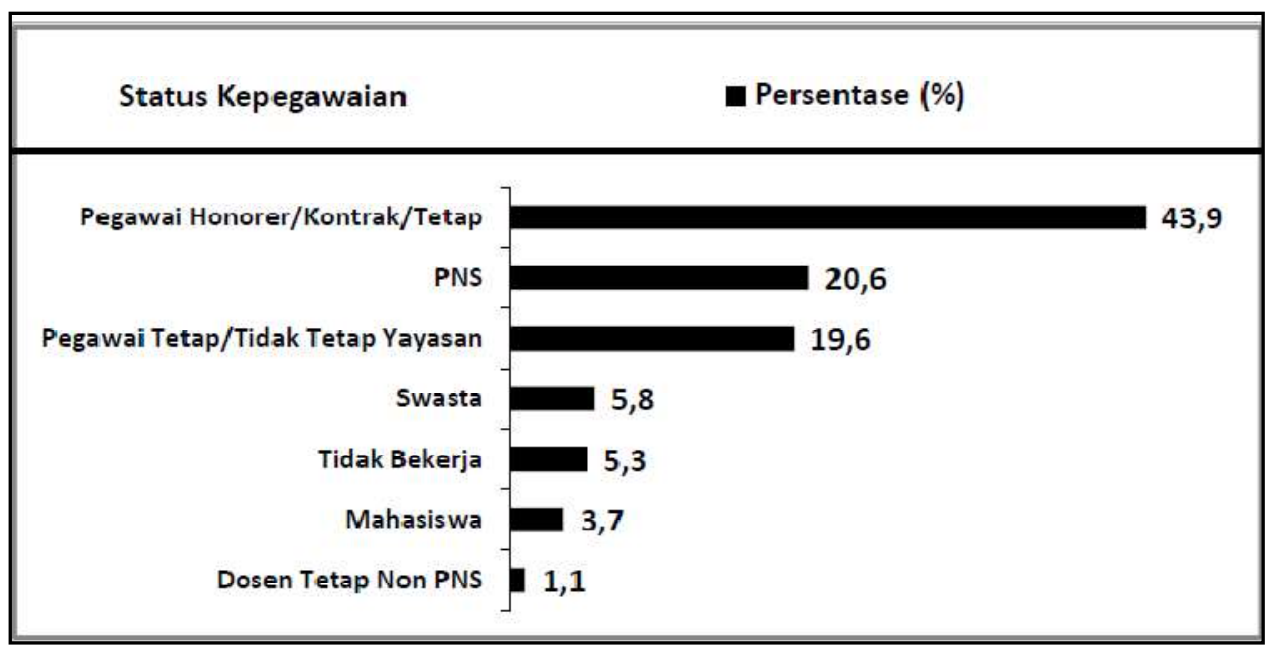

Gambar 6. Status Kepegawaian Alumni 


\begin{tabular}{|l|l|}
\hline \hline Status Pendidikan Lanjutan & Persentase (\%) \\
\hline Belum Studi Lanjut & \\
Telah Selesai Studi & 13,3 \\
\hline Sedang Studi Lanjut & 8,5 \\
\hline
\end{tabular}

Gambar 7. Status Pendidikan Lanjutan Alumni

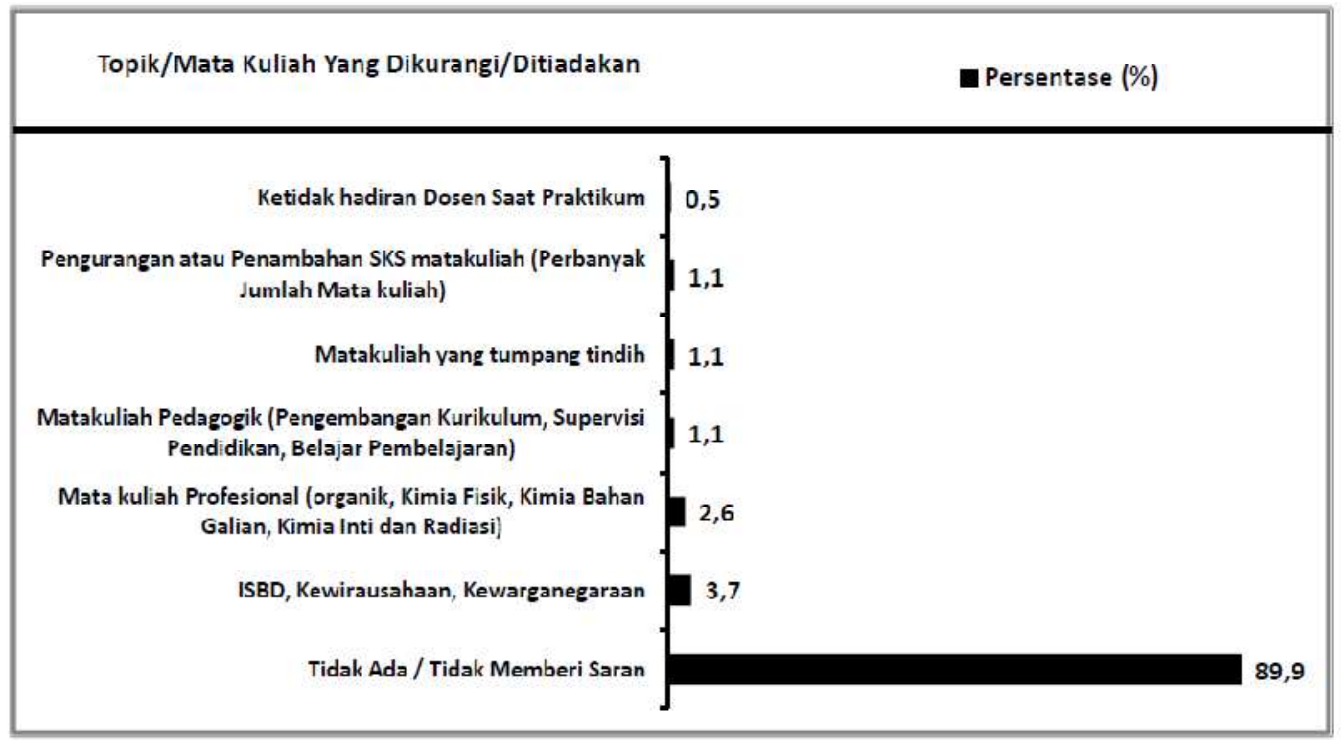

Gambar 8. Topik/Mata Kuliah yang Dikurangi/Ditiadakan

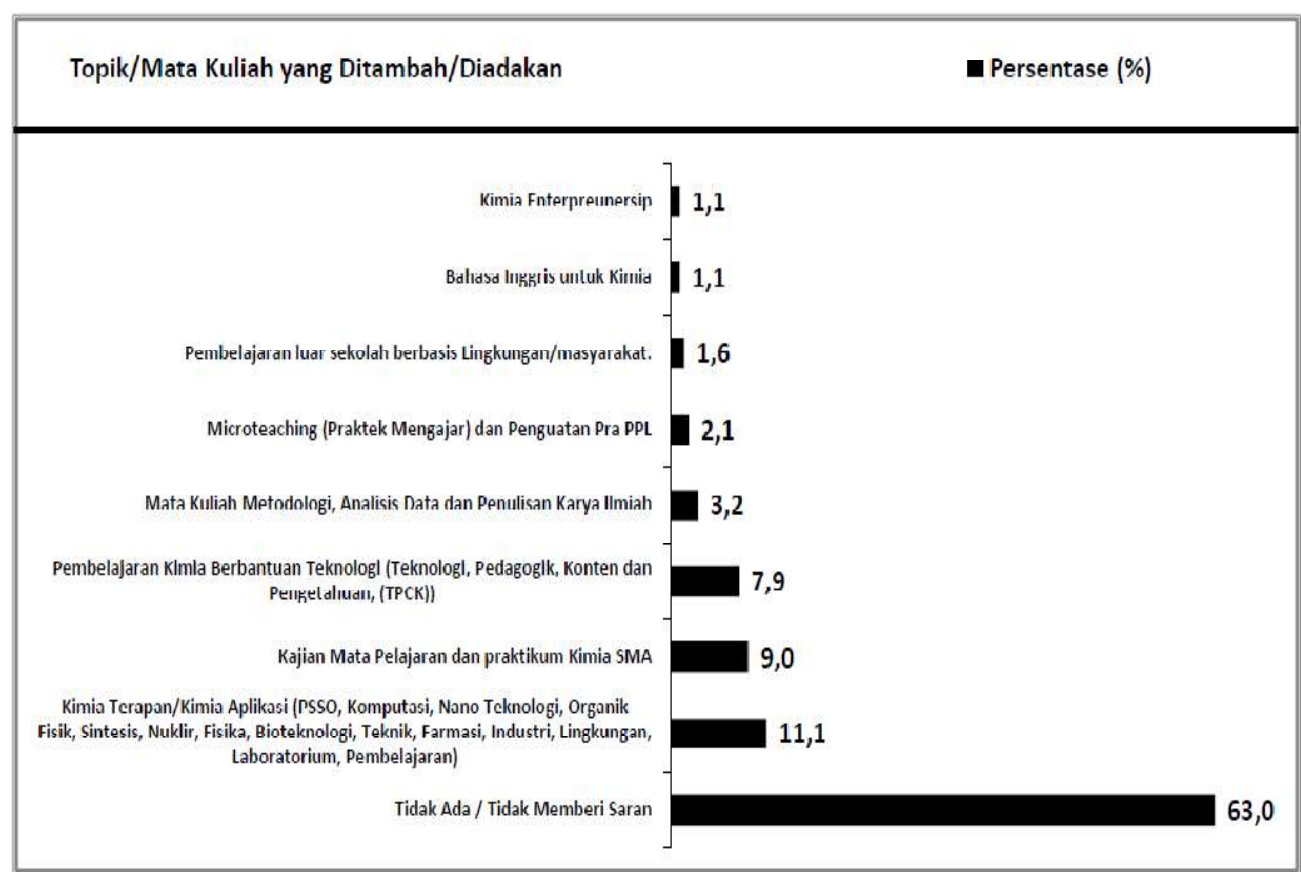

Gambar 9. Topik/Mata Kuliah yang Ditambah/Diadakan 


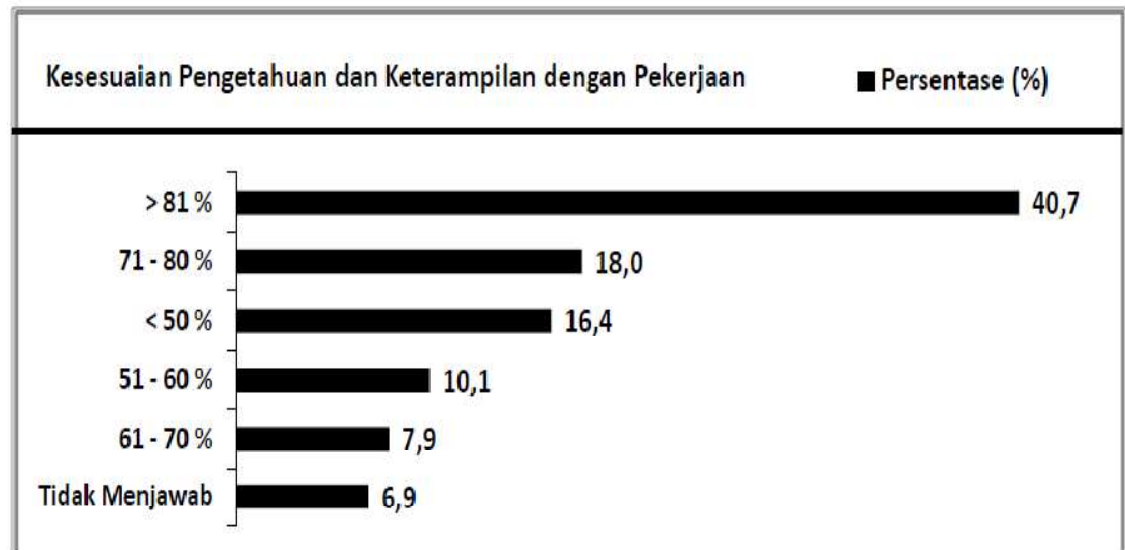

Gambar 10. Kesesuaian Pengetahuan dan Keterampilan dengan Pekerjaan

\begin{tabular}{|c|c|}
\hline Proses Pembelajaran yang dlperbalkl/ditlngkatkan & - Persentase (\%) \\
\hline Aspek Pembelajaran (Sudah baik, Bagus dan Lengkap) & 2,1 \\
\hline $\begin{array}{c}\text { Pembelajaran Kontekstual (Pada Kegiatan Praktikum Maupun } \\
\text { Pembelajaran Lapangan) }\end{array}$ & 2,6 \\
\hline $\begin{array}{l}\text { Peningkatan Kualitas SDM (Pengajar) pada Kegiatan Perkuliahan } \\
\text { maupun Bimbingan }\end{array}$ & 3,2 \\
\hline $\begin{array}{l}\text { Peningkatan Kualitas Pelaksanaan Praktikum (Peningkatan } \\
\text { Kualitas Alat, Bahan dan Pelaksanaan Praktikum) }\end{array}$ & 3,2 \\
\hline Penerapan Metode Perkuliahan yang bervariatif (Aspek PAIKEM) & 5,3 \\
\hline $\begin{array}{l}\text { Peningkatan Kualitas Kemampuan Lulusan (Berpikir } \\
\text { Kritis, Kreatif, Inovatif, Komunikatif, Kolaboratif, serta Profesional) }\end{array}$ & 5,8 \\
\hline Tidak Ada / Tidak Memberi Saran & 77,8 \\
\hline
\end{tabular}

Gambar 11. Proses Pembelajaran yang diperbaiki/ditingkatkan

\begin{tabular}{|r|r|}
\hline Sarana dan Prasarana yang Perlu ditingkatkan & 口 Persentase (\%) \\
\hline $\begin{array}{r}\text { Peningkatan Kualitas Lulusan (Persyaratan } \\
\text { TOEFL, Pembentukan Kelas Model) } \\
\text { Peningkatan Kualitas Pelayanan SDM } \\
\text { (Perkuliahan, Kebersihan gedung, Kamar Mandi) }\end{array}$ & $\mathbf{1 , 1}$ \\
Optimalisasi Pembelajaran melalui Laboratorium Multimedia \\
(Media Pembelajaran, Pembelajaran Interaktif, Alat Peraga) \\
Peningkatan Fasilitas Sarana dan Prasarana Ruangan \\
(Dosen, Belajar, Akses Internet, LCD, AC) \\
Peningkatan Sarana dan Prasarana Ruang Praktikum \\
Peningkatan Kualitas dan Kuantitas Alat dan bahan \\
laboratorium \\
Tidak Ada / Tidak Memberi Saran
\end{tabular}

Gambar 12. Sarana dan Prasarana yang perlu diperbaiki/ditingkatkan

\section{Status Kepegawaian Alumni}


Berdasarkan hasil tabulasi data diperoleh informasi Status Kepegawaian Alumni saat ini terpadat pada gambar 6 . Berdasarkan gambar (6) diperoleh informasi bahwa Status Kepegawaian Alumni saat ini secara berurutan adalah Pegawai Honorer/Kontrak/Tetap Sebesar 43,9\%, Pegawai Negeri Sipil (PNS) 20,6\%, Pegawai Tetap/Tidak Tetap Yayasan 19,6\%, Swasta 5,8\%, Tidak Bekerja $5,3 \%$, Mahasiswa 3,7\%, dan Dosen Tetap non PNS $1,1 \%$.

\section{Status Pendidikan Lanjutan}

Berdasarkan hasil tabulasi data diperoleh gambaran informasi Status Pendidikan Lanjutan Alumni berdasarkan gambar (7) adalah sebagai berikut : Belum Studi Lanjut 78,3\%, Telah Selesai Studi (S2/S3) 13,2\% dan masih sedang studi (S2/S3) sebesar 8,5\%.

\section{Hasil Angket Responden}

Berdasarkan respon alumni yang telah dikumpulkan, analisis hasil respon quesioner difokuskan pada 3 aspek utama dalam mendukung penyelenggaraan pendidikan yaitu: 1). Kurikulum (Berisikan Topik/Mata kuliah yang perlu dikurangi/ditiadakan dan Topik/Mata kuliah yang perlu ditambah/diadakan serta Kesesuaian Pengetahuan dan keterampilan yang diperoleh dari program studi dengan tuntutan pekerjaan), 2). Proses Belajar Mengajar (Proses Pembelajaran yang perlu diperbaiki/ditingkatkan), 3). Sarana dan Prasaran Perkuliahan maupun Praktikum (Sarana dan Prasarana yang perlu ditingkatkan). Dibagian akhir juga disajiakan masukan - masukan dari alumni yang dapat digunakan sebagai bahan pertimbangan dalam pengambilan kebijakan.

\section{Kurikulum \\ a. Topik/Mata kuliah yang perlu dikurangi/ditiadakan}

Berdasarkan gambar (8) diperoleh informasi tentang Topik/Mata kuliah yang perlu dikurangi/ditiadakan berdasarkan respon alumni adalah sebagai berikut: Tidak ada/Tidak Memberi Saran, 89,9\%, ISBD, Kewirausahaan, Kewarganegaraan 3,7\%, Mata Kuliah Profesional (kimia organik, Kimia Fisik, Kimia Bahan Galian, Kimia Inti dan Radiasi) 2,6\%, Mata Kuliah Pedagogik (Pengembangan Kurikulum, Supervisi Pendidikan, dan Belajar Pembelajaran) 1,1\%, Pengurangan atau Penambahan SKS Mata Kuliah (Perbanyak Jumlah Mata Kuliah) 1,1\% dan Ketidakhadiran Dosen saat Praktikum 0,5\%.

\section{b. Topik/Mata kuliah yang perlu ditambah/diadakan}

Berdasarkan hasil tabulasi data pada gambar (9) diperoleh informasi Topik/ Mata kuliah yang perlu ditambah/diadakan yang dikelompokkan berdasarkan reduksi data responden alumni. Adapun Topik/Mata Kuliah yang Ditambah/Diadakan antara lain: Tidak ada/Tidak Memberi Saran, 63,0\%, Kimia Terapan/Kimia Aplikasi (PSSO, Komputasi, Nano Teknologi, Organik Fisik, Sintesis, Nuklir, Fisika, Bioteknologi, Teknik, Farmasi, Industri, Lingkungan, Laboratorium, Pembelajaran), 11,1\%, Kajian Mata Pelajaran dan Praktikum Kimia SMA, 9,0\%, Pembelajaran Kimia Berbantuan Teknologi (Teknologi, Pedagogik, Konten dan Pengetahuan (TPCK)), 7,9\%, Mata Kuliah Metodologi, Analisis Data dan Penulisan Karya Ilmiah, 3,2\%, Microteaching (Praktek Mengajar) dan Penguatan Pra PPL, 2,1\%, Pembelajaran luar sekolah berbasis Lingkungan/Masyarakat, 1,6\%, Bahasa Inggris untuk Kimia, 1,1\% dan Kimia Enterpreunersip, $1,1 \%$.

\section{c. Kesesuaian Pengetahuan dan keterampilan dengan pekerjaan}

Berdasarkan hasil tabulasi data diperoleh informasi Kesesuaian Pengetahuan dan keterampilan yang diperoleh dari program studi dengan tuntutan pekerjaan yang dikelompokkan berdasarkan reduksi data responden pada gambar 10. Berdasarkan gambar (10) diperoleh gambaran tentang Kesesuaian Pengetahuan dan Keterampilan dengan Pekerjaan antara lain: Responden yang merasakan kesesuaian pengetahuan dan keterampilan dengan pekerjaan $>81 \%$ adalah sebanyak 40,7\%, 71 - 80\% sebanyak 18,0\%, $61-$ $70 \%$ sebanyak $7,9 \%, 51-60 \%$ sebanyak $10,1 \%$ dan yang merasakan kesesuaian pengetahuan dan keterampilan dengan pekerjaan responden yang kurang dari $50 \%$ sebanyak $16,4 \%$.

\section{Proses Belajar Mengajar}

Berdasarkan hasil tabulasi data diperoleh informasi yang berkaitan dengan proses belajar mengajar (dalam bentuk saran-saran yang diberikan responden yang berkaitan dengan proses pembelajaran yang sudah mereka rasakan selama menjadi mahasiswa yang perlu diperbaiki/ditingkatkan). Jawaban responden berupa saran-saran perbaikan tersebut kemudian dikelompokkan peneliti dengan cara reduksi data responden menjadi tujuh (7) kelompok jawaban. Adapaun saran-saran yang diutarakan berkaitan proses belajar mengajar digambakan seperti gambar 11. Berdasarkan gambar (11) diperoleh gambaran tentang Proses Pembelajaran yang diperbaiki/ditingkatkan antara lain : Tidak ada/Tidak Memberi Saran, 77,8\%, Peningkatan Kualitas Kemampuan Lulusan (Berpikir Kritis, Kreatif, Inovatif, Komunikatif, Kolaboratif, serta Profesional), 5,8\%, Penerapan Metode Perkuliahan yang bervariatif (Aspek PAIKEM), 5,3\%, Peningkatan Kualitas Pelaksanaan Praktikum 
(Peningkatan Kualitas Alat, Bahan dan Pelaksanaan Praktikum), 3,2\%, Peningkatan Kualitas SDM (Pengajar) pada Kegiatan Perkuliahan maupun Bimbingan, 3,2\%, Pembelajaran Kontekstual (Pada Kegiatan Praktikum maupun Pembelajaran Lapangan), 2,6\% dan yang menyatakan Aspek Pembelajaran (Sudah baik, Bagus dan Lengkap), 2,1\%.

\section{Sarana dan Prasaran Perkuliahan maupun Praktikum}

Berdasarkan hasil tabulasi data diperoleh informasi yang berkaitan dengan Sarana dan Prasarana Perkuliahan maupun Praktikum (dalam bentuk saran-saran yang diberikan responden yang berkaitan dengan Sarana dan Prasarana Perkuliahan maupun Praktikum yang perlu diperbaiki/ditingkatkan). Jawaban responden berupa saran-saran perbaikan tersebut kemudian dikelompokkan peneliti dengan cara reduksi data responden menjadi tujuh (7) kelompok jawaban. Adapaun saran-saran yang diutarakan berkaitan Sarana dan Prasarana tersebut digambakan seperti di bawah ini :

Berdasarkan gambar (12) diperoleh gambaran tentang Sarana dan Prasarana yang perlu diperbaiki/ditingkatkan antara lain : Tidak ada/Tidak Memberi Saran, 69,8\%, Peningkatan Kualitas dan Kuantitas Alat dan bahan laboratorium, 10,1\%, Peningkatan Sarana dan Prasarana Ruang Praktikum, 9,5\%, Peningkatan Fasilitas Sarana dan Prasarana Ruangan (Dosen, Belajar, Akses Internet, LCD, AC), 4,8\%, Optimalisasi Pembelajaran melalui Laboratorium Multimedia (Media Pembelajaran, Pembelajaran Interaktif, Alat Peraga), 3,2\%, Peningkatan Kualitas Pelayanan SDM (Perkuliahan, Kebersihan gedung, Kamar Mandi), 1,6\%, Peningkatan Kualitas Lulusan (Persyaratan TOEFL, Pembentukan Kelas Model), 1,1\%.

\subsection{Masukan, Kritik, dan Saran Responden untuk Program Studi}

Dalam sub bagian ini akan disajikan beberapa masukan, kritik, dan saran dari alumni mengenai 3 aspek utama (Kurikulum, Proses Belajar dan Sarana Prasarana Perkuliahan maupun Praktikum) diantaranya :

\section{Kurikulum}

a. Program studi dituntut untuk mampu membuat terobosan dan mensinergikan kurikulum yang diberlakukan di program studi untuk menjawab tantangan dunia kerja yang dihadapi alumni misalnya, penambahan mata kuliah aplikasi atau mata kuliah terapan berbasis kearifan lokal, mata kuliah kajian pembelajaran materi di SMA serta Mata kuliah Luar Sekolah berbasis lingkungan atau masyarakat sehingga memungkinkan alumni tidak hanya menjadi guru tetapi memiliki peluang juga menjadi enterpreneursip sesuai dengan keilmuannya.

b. Program studi juga dituntut untuk mampu mengevaluasi kurikulumnya terutama untuk mata kuliah yang tumpang tindih materinya serta mengurangi jumlah SKS matakuliah dengan sks besar menjadi mata kuliah dengan SKS sedikit sehingga akan dimunculkan banyak varian mata kuliah. Selain itu jumlah mata kuliah MKDU hendaknya dikurangi jumlahnya dengan menambahkan matakuliah yang mendukung kompetensi profesional lulusan.

\section{Proses Belajar}

Pada Proses belajar mengajar beberapa alumni menekankan evaluasi metode pembelajaran yang diterapkan dosen (menekankan pembelajaran yang kontekstual, memberikan contoh yang kongkrit) sehingga pembelajaran menjadi bermakna. Selain itu efektifitas pembelajaran juga diperlukan misalnya pengurangan jumlah mahasiswa dalam satu kelas sehingga memungkinkan semua mahasiswa mendapatkan informasi yang lengkap dan jelas dari dosennya, serta interaksi dosen dan mahasiswa dalam kelas menjadi lebih intensif.

\section{Sarana dan Prasarana Perkuliahan maupun Praktikum}

Untuk sarana dan prasarana, karena program studinya adalah pendidikan kimia, maka yang paling dibutuhkan oleh mahasiswa selain sarana dan prasarana perkuliahan yang baik dan nyaman juga fasilitas ruang laboratorium yang memadai baik peralatan maupun bahan yang digunakan praktikum. Adanya peningkatan kualitas dan kuantitas Laboratorium, peralatan dan bahan praktikum akan memungkinkan tumbuhnya kebiasaan ilmiah mahasiswa yang kelak pengetahuan dan pengalamannya di laboratorium tersebut dapat menjadi bekal yang cukup untuk menghadapi tantangan dunia kerja. Terlebih lagi dunia kerja yang paling banyak dimasuki alumni adalah menjadi Guru/Dosen atau instruktur bimbingan belajar bidang kimia yang nota bene mereka dituntut untuk mampu menunjukkan keahliannya baik keahlian keilmuannya secara teoritis maupun keahliannya secara praktek.

\section{KESIMPULAN}

Berdasarkan uraian di atas hasil kajian dalam penelitian ini menunjukkan bahwa:

1. Berdasarkan data responden hasil penelusuran alumni diketahui bahwa lulusan pendidikan kimia yang telah terserap dunia kerja sebanyak 79,9\% pada berbagai sektor pekerjaan.

2. Bidang Pekerjaan pertama yang diperoleh setelah lulus adalah sebagai guru/Dosen Mata Pelajaran Kimia yaitu sebanyak 36,5\%.

3. Bidang Pekerjaan alumni Pendidikan Kimia yang sesuai dengan keilmuannya sebanyak $56,6 \%$ dengan 
bidang pekerja yang paling banyak digeluti adalah sebagai Guru Mata Pelajaran Kimia (39,2\%)

4. Kesesuaian pengetahuan dan keterampilan yang diperoleh dari program studi dengan tuntutan pekerjaanya (kesesuaian lebih dari $81 \%$ ) adalah $40,7 \%$.

5. Status kepegawaian alumni paling banyak adalah sebagai pegawai honorer/kontrak/tetap sebanyak $43,9 \%$.

\section{SARAN}

Berdasarkan temuan di atas, saran yang perlu mendapatkan perhatian dalam kajian ini adalah :

1. Program studi dituntut untuk secepatnya melakukan rekonstruksi kurikulum, untuk menyesuaikan atau mensingkronkan kurikulum yang ada dengan perkembangan dunia pendidikan sekarang misalnya penyesuaian dengan Permendikti No 55 Tahun 2017 tentang Standar Pendidikan Guru.

2. Perlu langkah konkrit program studi untuk mengakomodasi saran alumni berdasarkan pengalaman lapangan misalnya memunculkan Mata Kuliah Terapan/Aplikatif berbasis kearifan lokal, Mata Kuliah kajian pelajaran SMA, Mata Kuliah pembelajaran luar sekolah berbasis masyarakat/lingkungan, mengevaluasi mata kuliah yang materinya tumpang tindih, mengurangi SKS Mata Kuliah sehingga muncul Mata kuliah yang lebih variatif, dan lain-lain.

3. Perlu dilakukan kajian penelusuran terhadap lulusan Program studi secara lebih komprehensif dan detail agar bisa memberikan kontribusi positif untuk kemajuan Program studi dalam menjawab tantangan dunia kerja. Oleh karena itu patut dipertimbangkan untuk disusun basis data alumni berbasis digital (on line) agar selalu dapat diperbarui dan mudah diakses.

\section{DAFTAR PUSTAKA}

[1] Handayani, T. (2015). Relevansi Lulusan Perguruan Tinggi di Indonesia dengan Kebutuhan Tenaga Kerja di Era Global. Jurnal Kependudukan Indonesia, 10(1), 53-64.

[2] Roviati, E., Jalaludin, D., Fitria, E., Jaelani, E., \& Sari, L. L. (2015). Tracer study: Studi Rekam Jejak Alumni dan Respons Stakeholder Jurusan Tadris IPA-Biologi IAIN Syekh Nurjati Cirebon. Scientiae Educatia, 4(1).

[3] Kardoyo, K., \& Nurkhin, A. (2016). Analisis Kepuasan Pelayanan Perguruan Tinggi (Kasus pada Prodi Magister Pendidikan Ekonomi Unnes). Cakrawala Pendidikan, (2).

[4] Supriati, S., \& Handayani, T. (2018, November). Relevansi Lulusan Perguruan
Tinggi dalam Penempatan Kerja. In Seminar Nasional Industri dan Teknologi (pp. 9-18).

[5] Yoyet, E. (2009). Studi Pelacakan Alumni Politeknik Negeri Padang Sebagai Umpan Balik Menentukan Kebijakan Akademik dan Pasar Kerja. Jurnal Akuntansi \& Manajemen, 4(2), 93-102.

[6] ATMAJA, T. P. (2013). Pengembangan Tracer Study Berbasis Web. PROCIDING KMSI, 1(1).

[7] Yani, D. E., Pertiwi, P. R., Fadila, I., Puspitasari, K. A., \& Huda, N. (2012). Tracer study pada Program Studi S1 Agribisnis FMIPA-Universitas Terbuka. Jurnal Pendidikan Terbuka Dan Jarak Jauh, 13(2), 94-105.

[8] Sintiani, I., Fitriani, L., \& Kurniawati, R. (2017). Pengembangan Aplikasi Tracer Study STT-Garut. Jurnal Algoritma, 14(1), 118-124.

[9] Nugroho, Z. A., \& Arifudin, R. (2014). Sistem Informasi Tracer Study Alumni Universitas Negeri Semarang Dengan Aplikasi Digital Maps. Scientific Journal of Informatics, 1(2), 153-160.

[10] Karyono, G., \& Hermanto, N. (2013). Rancang Bangun Sistem Tracer Study Online pada STMIK AMIKOM Purwokerto. Semantik, 3(1).

[11] Khair, M., Astuti, I. F., \& Khairina, D. M. (2016). Alumni Tracer System Berbasis Web. In Prosiding Seminar Sains dan Teknologi FMIPA Unmul, Samarinda, Indonesia.

[12] Santoso, B., Mahmudi, H., \& Basuki, P. (2019). Studi Pelacakan (Tracer Study) Kinerja Lulusan Program Pascasarjana Magister Ilmu Ekonomi (MIE) Fakultas Ekonomi Dan Bisnis Universitas Mataram. Elastisitas-Jurnal Ekonomi Pembangunan, 1(1), 1-15.

[13] Karnan, K., Hadiprayitno, G., \& Santoso, D. (2019). Pengisian Basis Data Alumni Program Studi Pendidikan Biologi FKIP Universitas Mataram. Jurnal Pendidikan dan Pengabdian Masyarakat, 2(1).

[14] Daeng, A., Suriadi, I., \& Masrun, M. (2017). Studi Pelacakan Kinerja Lulusan Jurusan Ilmu Ekonomi dan Studi Pembangunan (IESP) Fakultas Ekonomi Dan Bisnis Universitas Mataram. Journal of Economics and Business, 3(1), 47-56.

[15] Japa, L., Prayitno, G. H., \& Mertha, I. G. (2018). Pembuatan Basis Data Alumni Program Studi Pendidikan Biologi Fkip Universitas Mataram. Jurnal Penelitian Pendidikan IPA, 4(1). 